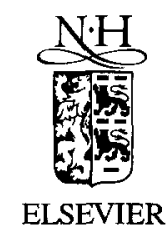

Research Policy 26 (1997) 391-403

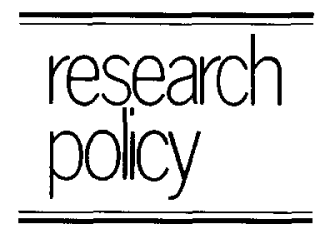

\title{
Patents, licensing, and market structure in the chemical industry
}

\author{
Ashish Arora * \\ Heinz School of Public Policy and Management, Carnegie Mellon University, Pittsburgh, PA 15213, USA \\ Received 10 March 1997
}

\begin{abstract}
The strategies of rent appropriation and industry structure are inter-dependent. How firms use patents depends upon industry structure, and in turn, affects industry structure. In the 19th century, market leaders in the chemical industry combined patents and secrecy to deter entry. Within cartels, patents were used to stabilize cartels and organize technology licensing. The role of patents changed in the less concentrated post World War II markets. In bulk organic chemicals and petrochemicals, chemical producers use licensing as an important means of generating revenue from process innovations. The increased importance of technology licensing is closely related to the emergence of a class of specialized process design and engineering firms that have played an important role in the development and diffusion of process innovations. (C) 1997 Elsevier Science B.V.
\end{abstract}

JEL classification: O34; L10; L65

Keywords: Patents; Licensing; Market structure; Chemicals

\section{Introduction}

The link between market structure and appropriability conditions has long been a subject of study in the economics of technical change. In the Schumpeterian view, (temporary) monopoly power encourages innovation in part because monopoly power is thought also to improve appropriability. By the same token, appropriability conditions have been identified as one of the key determinants of industry structure. (See for instance the review article by Cohen and Levin (1989), and the references cited there, for

\footnotetext{
* Corresponding author. Tel.: + 1-412-268-2191; e-mail: ashish@andrew.cmu.edu.
}

evidence on both linkages). However, much of the economics literature has focused largely upon patents as the key appropriability mechanism and moreover, typically identified a patent with a discrete innovation.

Patents are undoubtedly one of the instruments that firms use to capture rents from innovation, but there is mounting empirical evidence that the traditional economics view of patents is inadequate and even misleading. Patents are only one means of protecting technological investments, and often not the most important means of doing so. The results of the well-known Yale survey (Levin et al. (1987)) suggested that for most 'high tech' industries (except chemicals) patents are less effective than alternatives such as lead time, secrecy, and complimentary sales 
and service effort. ${ }^{1}$ Moreover, firms use patents in more subtle and sophisticated ways than simply as a legal barrier to deter rivals.

An investigation of the role of patents and the alternative mechanisms for appropriating the rents from innovation can illuminate the larger question of the relationship between appropriability regime and market structure. How do the efficacy and the role of patents change with industrial structure, and in turn, how does the changing role of patents affect industry structure? This question forms the point of departure for a somewhat selective examination of the historical role of patents in the chemical industry. This essay will focus primarily upon organic chemicals, defined broadly to include petrochemical building blocks, synthetic fibers, plastics, and other types of chemical products based upon petrochemical feedstocks.

Section 2 examines the strategies of firms in the pre World War I dyestuffs industry. The market leaders - the major German dyestuff companiesskilfully combined patents with secrecy to deter entry and preserve market leadership. During the interwar years, patents were used to preserve the international oligopolies and cartels that characterize this period. However, Section 3 argues that patents were also useful for facilitating flows of technological knowledge inside the cartels. After World War II, cartels greatly decreased in importance and important sectors of the chemical industry witnessed a great deal of entry. Section 4 argues that increased licensing of process technologies played a major role in enabling new firms to enter, and in turn, entry induced existing producers to increase licensing. Patenting is a pre-condition for the technology to be licensed. Section 2 therefore discusses how changing competitive conditions themselves affect the choice between licensing and self commercialization-exploiting innovations in-house. Section 6 summarizes and discusses the conclusions.

\footnotetext{
'Respondents from the chemical industry rated product patents as very important. And, while process patents were seen as ineffective in other industries, process patents in chemicals were rated as being effective.
}

\section{Combining patents and secrecy to deter entry}

Organic dyestuffs is one of the earliest of the science based 'high tech' sectors. Haber (1958) and Haynes (1954), among others, note that patents have played a key role in organic dyestuffs, at least since the latter part of the nineteenth century. A recent account of the research organization of the German chemical industry argues that serious research by these firms in the area of organic chemistry, particularly organic dyestuffs, began with the passage of the German Patent Law in 1877 that provided a common patent regime for all German states (Marsh, 1994). ${ }^{2}$ The law is said to have prevented companies from simply copying new chemical processes, as they had done earlier, and thereby induced firms to undertake research, both to discover new processes and products, and to invent around others' patents. These investments in research helped Germany rapidly overtake Britain as the leading producer of organic dyestuffs. Having obtained an early lead in organic dyestuffs, German companies used patents systematically to exclude competitors and preserve their market position, both at home and in other countries as well. Liebenau (1992), p. 65, states that

In outline, the strategy involved patenting as many potentially interesting products of industrial $R \& D$ as possible.... Patents were taken out to build walls around whole research areas.... This strategy was certainly recognized by the three leading German firms by the end of the 19th century. From that time, the big three, Bayer, BASF, and Hoechst owned between them $66 \%$ of all German held US chemical patents. ${ }^{3}$

However, the role played by know-how, usually protected by secrecy, is less well understood. Hounshell and Smith (1988), pp. 89-90, describe how

\footnotetext{
${ }^{2}$ Haber (1958), p. 293, cites evidence that for the period 1877-1904, out of 12,128 chemical patents in Germany, 3447 were for processes for bleaching and dyeing and 3733 related to processes for preparing colors, lacquers and varnishes.

${ }^{3}$ IG Farben continued this strategy. In 1936, IG Farben held 4000 patents in the US, and was receiving new ones at the rate of about 300 per year (Smith (1992: 147)).
} 
German companies skilfully combined patents and secrecy to keep potential imitators at bay. The dyestuffs were typically composed of a number of different compounds. In some cases, the precise composition of the dyestuff was kept secret, but the individual compounds protected by patents. In other instances, dyestuff patents described the results of a certain process, without specifying which particular by-product of the process gave rise to the actual coloring material. In other cases, entire groups of compounds would be patented, with only a fraction having properties similar to the dye of interest, so that a rival would have to undertake elaborate and costly experimentation to discover the actual composition of the dyestuff placed on the market. To minimize the information disclosed, German firms also issued misleading 'evasion' patents. The net effect was that would-be competitors found it very difficult to establish a clear relationship between dyestuff patents and the dyestuffs sold on the markets. These so called 'unclassified' dyes commanded significant price premia, often selling for $40-50 \%$ over the standard colors whose composition was known.

The importance of know-how and trade secrets, and their complementarity with patents is illustrated by the history of dyestuffs in the US. During World War I, the British blockade prevented German dyestuffs from reaching the US and prompted Du Pont to enter the dyestuffs business. To this end, it entered into a collaboration with Levinstein, a British firm which had access to a Hoechst plant confiscated by the British government, and hired a consultant familiar with dyestuffs that BASF sold in the US, Maurice Poucher. In 1919, Du Pont also managed to get access to all German patents from the Chemical Foundation, which offered non-exclusive licenses on royalty basis on all German patents in the US expropriated as a result of World War I. By this time Du Pont had already spent US $\$ 11$ million on strengthening its capability in the dyestuffs area (Hounshell and Smith, 1988, p. 94). But despite all this, Du Pont also had to undertake a clandestine campaign to lure away (in violation of the US and German trade secrecy laws) several chemists working in German companies, by offering them ten to fifteen times their German salaries. Hounshell and Smith (1988) p. 96, conclude that the "... recruitment of German chemists definitely aided [Du Pont's] quest to become a profitable dyestuffs manufacturer".

In analyzing the choice between patents and secrecy, the literature has focused largely on the tradeoff between the protection that patents provide against 'reverse engineering' versus the information they disclose to potential imitators (e.g., Horstman et al., 1985). An important factor affecting this trade-off is the nature of the knowledge to be patented. Knowledge based on inductive and empiricist procedures is often difficult to protect through patents. This is not only because such knowledge is often difficult to codify but also because patent claims on such knowledge would have to be narrow to be valid. If so, patents would disclose a great deal of useful information to potential imitators. Well articulated knowledge, on the other hand, can lead to stronger and better defined patents. The logical course of action would be to patent the clearly articulable aspects of the technology, and to keep secret the rest.

The patenting strategies of German firms in organic dyestuffs illustrates this trade-off. In dyestuffs, many aspects of the development of organic dyes were poorly understood. Often the precise composition of the dye was not known, and empirical techniques for production were developed through trialand-error. The absence of a sound theoretical understanding did not preclude patenting, but it did raise potential cost of patenting via disclosure to rivals, outweighing the benefits of patenting. Hence, not only was the composition of the dye sometimes kept secret and not patented, other characteristics of the dyestuff critical to its performance, such as the way in which the constituent elements were ground and mixed, were often not disclosed in patents. ${ }^{4}$ Historical accounts indicate that the skilful combination of patents, secrecy, and know-how played an important

\footnotetext{
${ }^{4}$ The prevailing patent law encouraged such a strategy. Early German law provided for process patents but not for product patents. Thus, there was no incentive (and indeed, a disincentive) to disclose the precise composition of the dyestuff. Moreover, in contrast to present day US patent law which requires 'enabling disclosure'-disclosure that would allow one skilled in the arts to carry out the invention - the patent law of the day appears to have been far less stringent on this subject. An interesting avenue of inquiry is the extent to which these changes were inspired by the historical experiences such as those discussed above.
} 
role in deterring entry by competitors in organic dyestuffs, at least till the first world war. (See for instance, Travis (1993), and Haber (1971)).

The strategic mix of patents and secrecy to deter entry into a technological area was not confined to dyestuffs. It was tried in other areas where the German companies were market leaders. The Haber-Bosch process for ammonia, a truly significant process innovation, was protected by more than 200 patents that covered the apparatus, temperatures, and pressures, but avoided particulars about the catalysts employed or their preparation. The catalyst was critical to the successful operation of the process, and keeping it secret significantly increased the expense and time for firms trying to circumvent the Haber-Bosch patent (Haynes (1954): V II, pp. 86$87)$. It is no coincidence that the discovery and the preparation of the catalyst was overwhelmingly empiricist and inductive. By contrast, the temperature and pressure conditions were determined (by Fritz Haber) by a more deductive procedure, where the experimental work was guided by theoretical principles of thermodynamics and principles of reaction equilibrium.

\section{Cartels and patent licensing}

The German strategy of using patents to 'build walls around entire research areas' was particularly successful when they had a substantial lead over their rivals. But over time, some firms, such as ICI and Du Pont, at times helped by their national governments, managed to reduce the gap. The narrowing gap, and the help of their respective governments provided these leading firms with a protected home market and led to the formation of a number of international cartels. The chemical industry was probably one of the earliest 'global' industries and cartels, both domestic and international, were an important aspect of this globalization. Indeed, the pre-World War II international chemical market has been characterized by many as a sort of a 'gentlemen's club' (e.g., Spitz, 1988; Smith, 1992).

While some cartels, such as the alkali cartel, were purely about market sharing, others were organized around a common technology, and were often initiated by the patent holder. The latter would license the technology, often in exchange for a small financial stake. For instance, Solvay required that the licensees of his ammonia-soda process share any improvements with him, and in turn, these improvements were shared with Solvay's other licensees. This helped the Solvay retain control, as well as enable his process to remain competitive against rivals (Haber, 1958, p. 89, Hounshell, 1992). Although cartels had explicit market sharing rules, economic theory suggests that licensing agreements alone could have achieved many of the restrictive outcomes that the inter-firm agreements specified. ${ }^{5}$ For instance, Du Pont's cellophane license to Sylvania (a US subsidiary of a Belgian company) in 1933 specified a $2 \%$ royalty on sales up to quota (defined initially as $20 \%$ of the market with small increases over time), and $30 \%$ on sales above the quota. This contract implied that de facto the licensee would never find it profitable to produce more than the agreed upon amount, as was indeed the case (Hounshell and Smith, 1988, p. 177).

Cartels used a number of instruments, including patent licensing agreements, to maintain market shares and deter entry. However, patents were more effective in deterring entry by smaller, less established firms. When challenged by a large firm, in many instances the innovating small firm licensed the technology to avoid having the patent validity challenged in court. Often it was not even in the imitator's interest to have the patent invalidated because it would allow entry of other firms. Innovating firms would enter into cross-licensing arrangements with each other but firms which lacked proprietary technologies were unable to get licenses. ${ }^{6}$ Thus patents were used to prevent entry and provide stability to the existing market structure. But within the cartel, patents provided a way of organizing the

\footnotetext{
${ }^{5}$ Using a simple theoretical model of cournot oligopoly in the product market, one can show that a patent holder can design a licensing contract offered to all existing producers that replicates the monopoly outcome (see Katz and Shapiro (1986) for details).

${ }^{6}$ Writing of the last quarter of the nineteenth century, Haber (1958), p. 199, notes "...(S)oon, however, the number of British patents taken out by the Germans increased, while their willingness to grant licenses decreased... for British manufacturers made fewer discoveries of immediate commercial value and so lost business and they were also unable to secure licenses from Germans and Swiss inventors and so lost more business."
} 
purchase and sale of technology, and providing incentives for research, because compensation could be based on the patent positions.

For instance, ICI and Du Pont had a long standing agreement which involved technology licensing as well as the extensive sharing of information and know-how. The agreement also specified compensation for the transferred technology. This implied that even when the one company had control over the basic patents, both would have incentives to carry out further research in improving and developing the innovations. This implication is borne out by the available historical evidence, which suggests that both firms invested in research to improve their bargaining positions during technology negotiations. ${ }^{7}$ Hence, although ICI obtained the basic patent on polyester, Du Pont developed significant expertise in the production process based on its experience in nylon, and controlled the melt-spinning process which was crucial for successful commercialization. The two companies settled on a cross-licensing agreement, which allowed both companies to benefit from the other's innovation.

\section{The impact of licensing on market structure}

One of the major impacts of World War II was to change the way in which firms used technology licensing. The increased use of licensing in the post war period is most marked in process technologies in refining, petrochemicals and other sectors characterized by relatively homogenous products, large markets and large scale plants. During the war, the inter-firm diffusion of technology was enhanced due to government cooperative research programs such as the synthetic rubber program in the US, as well as greater mobility of personnel. Thus some of the hitherto less prominent firms (such as Monsanto, Dow, Phillips, and Hercules) acquired significant technological capability and experience, and thus were attractive potential licensees. In some instances,

\footnotetext{
${ }^{7}$ Taylor and Sudnik (1984) quote an ICI manager as claiming that Du Pont deliberately carried out research in polyethylene process technology, on which ICI had the composition of matter patent, to gain better terms for licensing. Hounshell and Smith (1988) p. 200) confirm that Du Pont patented its improved lower-pressure process to improve its bargaining positions.
}

these firms developed new technologies which they were not always well suited to commercialize by themselves, and thus offered for licensing.

The post war era also witnessed the rise of a new of type of firms that specialized in the development and sale of process technologies. These specialized engineering firms, SEFs henceforth, have been important sources of process innovations. But what is more important how they appropriated the rents: Lacking the assets required to commercialize their innovations themselves, SEFs used licensing as the principal way of profiting from their innovations. In so doing, they enabled a number of firms to enter new markets, as well as changed the way in which established firms viewed technology licensing.

The rise of SEFs is closely linked to the tremendous growth in the use of oil and natural gas, instead of coal, as the basic raw material the chemical industry. As a result, many oil companies became important players in the petrochemical market. Oil companies had long paid attention to improving their processes. In contrast to chemical companies, which were very secretive about their production processes, oil companies were more open about their technical operations. Also, petrochemical plants are very large and complex, and constructing and operating them is a challenging task, where specialization is valuable. Indeed, from very early in this century, oil firms used specialized sub-contractors in various capacities. ${ }^{8}$ As these specialized engineering-construction firms (SEFs) grew in their ability to handle more sophisticated tasks, process design became a part of their activities as well.

The first SEFs were formed in the early part of the 20th century, typically in the US. By the 1960s, SEFs had come to occupy an important place in the industry. In a pioneering study, Freeman noted that for the period 1960-66, “ "... nearly three quarters of the major new plants were 'engineered', procured and constructed by specialist plant contractors" (Freeman, 1968, p. 30). As SEFs became important

\footnotetext{
${ }^{8}$ Oil companies perceived control over oil deposits, and distribution networks as more important strategic variables, as compared with refining technology. As one source has characterized the situation, large oil companies concentrated their energies on "...searching for crude oil and establishing retail market facilities..." (Landau and Brown, 1965 p. 35).
} 
sources of plant design, their importance as sources of process innovation also increased (Mansfield et al., 1977). ${ }^{9}$ As noted above, SEFs have relied upon licensing to appropriate rents from their innovations. Freeman showed that for the period 1960-66, SEFs as a group accounted for about $30 \%$ of all licenses (for processes). In a more recent study, Arora and Gambardella (1996) find that for the period 1970-90, in refining and petrochemicals (defined broadly to include basic chemicals such as ammonia, plastics, and synthetic fibers) SEFs accounted for over $45 \%$ of the total licenses granted. ${ }^{10}$

SEFs concentrated upon processes, and upon the design of plants. ${ }^{11}$ Thus, a division of labor developed in process innovation in sectors where a separation between process and product innovation was easier-namely, in large volume, organic intermediates. Effective process patents were a pre-condition for such a division of labor. Without patent protection, process innovations could only be protected through secrecy. But secrecy is not always a viable strategy if the objective is to license the technology: Although trade secrets can be licensed, as a practical matter, even such transactions are facilitated by patents. For instance, Taylor and Silberston (1973), p. 114, report that although most of the licensing agreements they analyzed had transfer of know-how as the major objective, most involved patents as

\footnotetext{
${ }^{9}$ UOP, and Scientific Design-Halcon are two of the SEFs that have radical innovations to their credit. UOP has a number of catalytic refining and reforming processes which it has licensed widely. Scientific Design pioneered a number of new pathways to produce basic inputs for synthetic fibers and plastics, such as the air oxidation process for para-xylene (used for polyester). A number of other SEFs have contributed to advances in engineering design. For instance M.W. Kellogg made significant contributions to developing high-pressure processes for ammonia in the 1930s, while Badger is associated with fluidized bed catalytic processes (in collaboration with Sohio).

${ }^{10}$ All licenses are process licenses. The dataset covered the period 1970-90, and was based on data on about 20,000 plants all over the world. It should be noted that the percentage refers only to cases where we could discover the identity of the licenser. If we consider all plants, the figure drops to about $30 \%$, similar to the figure reported by Freeman (1968).

${ }^{11}$ Product innovation requires close links with downstream buyers, and the technical ability and financial resources to undertake costly market development, which SEFs lack.
}

well. ${ }^{12}$ In addition to having patent protection, process technologies also had to be articulable in abstract terms, independent of the details of the particular producer or product, or else the cost of technology transfer would outweigh the benefits of specialization.

The development of chemical engineering played an important role in both respects. A chemical engineer could therefore see common elements across a number of processes which might appear very different and diverse to a chemist from an earlier generation. In other words, chemical engineering developed more general and abstract ways of conceptualizing chemical processes, thereby directly reducing transaction costs of licensing technology. ${ }^{13}$ Chemical engineering (and the concomitant developments in polymer science and surface chemistry) also provided the language for describing more precisely the innovations, as well as the scope of innovations. Greater precision in the description of the innovation allowed more effective patent protection, because pioneering patents could be broad without being invalid. As Haber (1971), p. 219, notes, that chemical engineering was a key factor in the licensing of technologies in high pressure synthesis, and plastics, because "...the process details lent themselves readily to licensing...'. By offering a package comprising of core technology, engineering design and know-how, and contract construction services, SEFs significantly lowered entry barriers for new firms.

The implications for industrial structure have been profound. Spitz (1988), p. 313, notes that in most major products, the number of major producers was between five and fifteen. By contrast, in the preWorld War II era, it was unusual to have more than three producers. This is confirmed by Table 1 , which

\footnotetext{
${ }^{12}$ In a study not limited to the chemical industry, I find that the provision of technical know-how (in the form of technical services) in international technology licensing contracts was strongly associated with patent protection (Arora, 1996).

${ }^{13}$ von Hippel (1990) has very interesting parallels with the ideas presented above. To use Von Hippel's terminology, more general and abstract knowledge makes specific information less 'sticky', while chemical engineering made possible a partitioning of the product and process developments.
} 
Table 1

Number of firms producing selected chemicals in the US

\begin{tabular}{lcc}
\hline Products & 1947 & 1961 \\
\hline Ammonia & 12 & 42 \\
Ethylene Glycol & 4 & 12 \\
Polyethylene & 2 & 14 \\
Xylene & 12 & 22 \\
Benzene & 11 & 33 \\
Alkalies and Chlorine & 18 & $18^{\mathrm{a}}$ \\
Cyclical (coal tar) crudes & 13 & $13^{\mathrm{a}}$ \\
Naphthalene & 12 & 13 \\
Phenol & 10 & 9 \\
\hline
\end{tabular}

Source: Compiled from Backman (1964), p. 7, and Table 4. ${ }^{a}$ Figure relates to 1958.

shows that the total number of producers in the bulk organic chemicals grew rapidly in the post war era, while the number of producers in bulk inorganic remained largely stable. The growth in the number of producers came about even though the minimum efficient scale of plants was increasing. It is also true that demand grew rapidly at this time, so that the fraction of entry that can be attributed to the increased licensing cannot be estimated precisely. There is ample anecdotal evidence that suggests that the increased availability of technologies, partly due to anti-trust efforts by the US government, and partly due to other developments discussed in Section 5, significantly lowered entry barriers (e.g., Backman, 1964 pp. 47-50).

Other studies provide evidence consistent with the hypothesis that the SEFs were major suppliers of technology and know-how to new entrants. In a study of 39 commodity chemicals in the US, from the mid ' 50 s to the mid '70s, Lieberman (1989) found that after controlling for demand conditions, experience accumulated by incumbents did not act to deter new entry. Given the importance of learning by doing, this suggests that entrants had access to other sources of know-how, most likely from SEFs. This interpretation is further supported by Lieberman (1989) findings that entry into concentrated markets, which were also marked by low rates of patenting by non-producers (both foreign firms and SEFs), usually required that the entrant develop its own technology. By contrast, less concentrated markets had higher rates of patenting by non producers and high rates of licensing to entrants. ${ }^{14}$ In a related study (of a subset of 24 chemicals) Lieberman (1987) found that high rates of patenting by non producers were also associated with faster rates of decline in prices. Once again, this evidence is consistent with an interpretation where patenting by non-producers (especially SEFs) led to entry by new firms through licenses.

Not only did SEFs promote entry in the US, they also led the diffusion and spread of modern technology, first to Europe, and then world wide, to Asia, East Europe, Latin America, and the middle East. The resulting increase in competition would later lead, in the 1980s and after, to a major restructuring of the industry in the US and Western Europe. As Arora and Gambardella (1996) document, a number of leading firms have been acquired or merged, and virtually all the major firms are concentrating on a smaller number of core businesses.

\section{The impact of market structure on licensing}

Not only did the licensing activities of the SEFs affect market structure by inducing entry, they also had a major effect on the licensing strategies of the chemical producers themselves. In a marked departure from their pre World War II strategy of closely controlling their technology, a number of chemical and oil companies began to use licensing as an important (although not the only) means of profiting from innovation. As Spitz (1988), p. 318, put it

\footnotetext{
${ }^{14}$ In their recent work, Cohen and Klepper (1992) have explored the implications of the absence of licensing of process imovations. Their theoretical model predicts that larger firms would tend to invest more in process $\mathrm{R}$ and $\mathrm{D}$, and therefore, would be more innovative in terms of output. In related work, Klepper (1996) extends this intuition to the analysis of industry structure. His model shows that early entrants that manage to survive and grow gain a large advantage over future entrants because the greater size of the former allows them to invest greater amounts in cost reducing process innovations. In time, future entry gets blocked because the size advantage of established firms proves overwhelming. Although first mover advantages have been substantial, both at the level of the firm as well as the product, there is evidence to the contrary as well. A prominent example is the recently reported exit of ICI from polyethylene, and polyester fiber, products which ICI had first commercialized, and for which it was one of the leading licensers in the world.
} 
... some brand new technologies, developed by operating (chemical) companies, were made available for license to any and all comers. A good example is the Hercules-Distillers phenol/acetone process, which was commercialized in 1953 and forever changed the way that phenol would be produced.

Another observer, Landau (1966), p. 4, writing two decades after the end of the war, noted that the " ... the partial breakdown of secrecy barriers in the chemical industry is increasing... the trend toward more licensing of processes."

The available evidence suggests that technology licensing is still quite widespread. Table 2 presents evidence for the period 1980-90 that indicates that the percentage of plants that involve an explicit reported licensing transaction varies from about $60 \%$ for petrochemicals to about $15 \%$ for pharmaceuticals. Of these reported licensing arrangements, a little over $80 \%$ involve sales of technology between firms not linked through ownership ties, with significant variations across different sub-sectors. Thus the data show that licensing is most common in sectors with large scale production facilities, with relatively homogenous products, and with a large number of new plants. It is less common in sectors marked by product differentiation, custom tailoring of products for customers, and small scales of production. Column $\mathrm{C}$ in Table 2 shows that SEFs account for a little less than half of these reported transactions. Note that these data do not distinguish between product and process licenses. In sectors such as petrochemicals, and fertilizers, the vast majority of licenses are process licenses. In other sectors, such as pharmaceuticals, and organic chemicals, the fraction of product licenses is likely to be higher. However, such sectors display lower overall rates of licensing in any case.

Table 2 shows that SEFs play a major role as licensers, but at least half the licenses sold to unaffiliated firms are by other chemical producers themselves. Some chemical companies that have been major licensers of their patented technologies include: ICI in ammonia, Union Carbide (UCC) in polyethylene and polypropylene, and in air separation technologies, Montecatini (including affiliates such as Himont) in polypropylene, and Mitsui in

Table 2

Licensing patterns in major chemical sectors, 1980-90, all countries

\begin{tabular}{|c|c|c|c|c|}
\hline & $\begin{array}{l}\text { Formal license }(\%) \\
\text { A }\end{array}$ & $\begin{array}{l}\text { Inter-firm (\%) } \\
\text { B }\end{array}$ & $\begin{array}{l}\text { Licenses by SEFs }(\%) \\
\mathrm{C}\end{array}$ & $\begin{array}{l}\text { Total projects } \\
\text { D }\end{array}$ \\
\hline Air Separation & 52.8 & 77.7 & 77.7 & 602 \\
\hline Fertilizers & 58.2 & 96.6 & 59.0 & 1395 \\
\hline Food Products & 25.2 & 82.6 & 34.8 & 365 \\
\hline Gas Handling & 28.5 & 95.2 & 67.3 & 1170 \\
\hline Inorganic Chemicals & 41.6 & 78.5 & 34.8 & 1535 \\
\hline Industrial Gasses & 57.8 & 91.2 & 55.2 & 536 \\
\hline Metals & 23.9 & 84.7 & 20.3 & 740 \\
\hline Organic chemicals & 36.3 & 57.3 & 17.5 & 1367 \\
\hline Organic refining & 53.8 & 91.0 & 53.6 & 2540 \\
\hline Petrochemicals & 57.6 & 83.6 & 40.9 & 3220 \\
\hline Pharmaceuticals & 16.6 & 50.6 & 6.1 & 892 \\
\hline Plastics & 51.1 & 63.2 & 12.9 & 2077 \\
\hline Paper & 19.1 & 96.1 & 7.9 & 533 \\
\hline Textiles and fibers & 62.3 & 84.6 & 34.4 & 487 \\
\hline Average & 45.2 & 81.1 & 39.6 & 18748 \\
\hline
\end{tabular}

Source: Author's calculations based on Pergamon Database.

Column A reports the percentage of new plants where a licenser was reported. Column B reports the percentage of reported licenses sold to firms that were unaffiliated with the licenser (i.e., are not subsidiaries, and do not have a common parent). Column $C$ reports the percentage of reported licenses sold by SEFs.

Sectors with fewer than 300 total plants between 1980-90 have been omitted.

The averages in the last row are weighted average for the entire database, including the sectors not included in the table.

In Air Separation, and Industrial Gasses, chemical companies such as UCC also build and supply plants, and were classified as SEFs for that purpose. 
Table 3

Licensing behavior of major chemical companies, 1980-90, all markets

\begin{tabular}{lllll}
\hline Rank & Company $^{\mathrm{a}}$ & $\begin{array}{l}\text { No. of Licenses as } \\
\text { \% of total investment }\end{array}$ & $\begin{array}{l}\text { Licenses as } \\
\text { \% of self investment }\end{array}$ & $\begin{array}{l}\text { Domestic licenses as } \\
\text { \% of domestic investment }\end{array}$ \\
\hline 1 & Bayer & 21 & 27 & 14 \\
2 & BASF & 20 & 24 & 8 \\
3 & Hoechst & 20 & 25 & 3 \\
4 & Du Pont & 16 & 19 & 6 \\
5 & Dow & 5 & 5 & 4 \\
6 & ICI & 3 & 30 & 12 \\
8 & UCC & 44 & 78 & 40 \\
9 & Shell & 32 & 46 & 18 \\
10 & Exxon & 23 & 30 & 16 \\
11 & Amoco & 35 & 53 & 26 \\
14 & Mobil & 25 & 33 & 20 \\
15 & Air Liquide & 21 & 27 & 9 \\
16 & Monsanto & 41 & 71 & 32 \\
17 & Montedison & 45 & 83 & 32 \\
18 & Enichem & 8 & 8 & 0 \\
& Average & 27 & 37 & 16 \\
\hline
\end{tabular}

Source: Author's calculations based on Pergamon Database.

${ }^{a}$ The companies are listed in order of chemical sales, based on Aftalian (1991) Appendix. I have omitted Allied Signal, Ciba-Geigy, Merck, and Proctor and Gamble, because they had very few plants listed in the database.

${ }^{\mathrm{b}}$ Total investment $=$ total number of new plants which were licensed by the company plus total number of new plants of the company in the period 1980-90; Self Investment $=$ total number of new plants of the company in the period 1980-90;Domestic licenses $=$ number of new plants which were licensed in its domestic market by the company;Domestic investments $=$ total number of new plants between $1980-90$ of the licenser company in its domestic market.

${ }^{\mathrm{c}}$ This is a weighted (by the number of new plants) average. The values are essentially unchanged even if one excludes the four oil companies-Amoco, Exxon, Mobil, and Shell.

polypropylene as well. Oil companies have been active in licensing their technologies. Shell, Mobil, $\mathrm{BP}$, and Amoco are some of the oil companies that have actively marketed their refining and petrochemical technologies.

Table 3 shows the licensing activities of 15 of the largest chemical producers (excluding pharmaceutical firms) in the world in the previous decade. It confirms what Table 2 suggested, namely that even the largest chemical firms license out their technologies, and some do so quite actively. Table 3 also shows quite clearly also that there are significant differences across companies in the extent to which they license their technology. A comparison of columns 3 and 4 shows that all companies are more likely to use licensing in dealing with overseas investments. Oil companies license more frequently than chemical companies, but there is considerable variation within the chemical companies themselves. Part of these inter firm differences reflect the differing importance of licensing across product groups (see Table 2), but others reflect differences in corporate strategy. The differences in corporate technology can be seen by comparing UCC and Dow, which are substantially similar in terms of the product markets in which they operate, but differ in their propensity to license.

The available evidence suggests that, if anything, firms are becoming more open to licensing. For instance, Dow, a company that has a reputation of very closely holding on to its technology, has begun actively licensing its technology in chlor-alkali (Brooks and Watzman, 1986) and metallocene catalyst based processes for polyethylene (Rotman, 1995). Its former CEO confirmed that this represented a change in strategy and not an isolated instance. ${ }^{15} \mathrm{~A}$ recent search of the trade publications turned up further anecdotal evidence that shows that,

\footnotetext{
${ }^{15}$ Frank Popoff, interview with the author, Midlands, MI, October 1995 .
} 
at least in some markets, chemical and oil companies aggressively compete to sell technology, often in collaboration with an SEF that undertakes to provide the engineering and other know-how. ${ }^{16}$

The question of whether or not licensing of proprietary technology by chemical firms is a long run profit maximizing strategy has been a matter of considerable debate in the industry itself. ${ }^{17}$ Licensing may imply increased competition and rent dissipation. In addition, transaction cost perspectives imply that contractual arrangements for the sale of technology involve inefficiencies and problems of enforcement (e.g., Teece, 1988), reducing the attractiveness of licensing as a means of rent appropriation. Caves et al. (1983) find that, due to imperfections in the licensing market, licensers capture only about a third of the rents from the innovation. In his remarks upon technology licensing, Arrow (1962) p. 355 , notes that:

One interesting feature... is the relatively low price paid for information. Patent royalties are generally so low that the profits from exploiting one's own invention are not appreciably greater than those derived from the use of others' knowledge. It really calls for some explanation why the firm that has developed the knowledge cannot demand a greater share of the resulting profits.

To understand the widespread use of licensing by major chemical producers, one must keep in mind that strategies of rent appropriation depend upon the existing market structure. Specifically, the presence of competing technologies and an increase in the

\footnotetext{
${ }^{16}$ Union Carbide and Himont compete with each other in selling polypropylene licenses, along with Amoco, which is a more recent entrant (Morris, 1989). BP and Du Pont compete in polyethylene process technology (Mullin, 1993). In methyl tert butyl ethers (MTBE), UOP, Mobil-BP, and Phillips Petroleum are amongst the competing licensers (Rotman, 1993a); in cumene, Mobil/Badger are the latest entrants in the licensing market which includes UOP, ABB Lummus Crest, and Monsanto/Kellog (Rotman, 1993b).

${ }^{17}$ For instance, an industry consultant criticized Union Carbide for the liberal licensing of its polypropylene/polyethylene Unipol process, claiming that licensing reduced profitability, both for the industry, and also for Union Carbide (Spalding, 1986). See also Spitz (1988) for similar views. On the other hand, in polypropylene, McMillan (1979), suggests that the licensing royalties earned by Montecatini (estimated by McMillan to be of the order of tens of millions of dollars) exceeded the profits that Montecatini earned from self production.
}

number of competing licensers drastically changes the payoff to the strategy of trying to keep one's technology in-house. ${ }^{18}$ For instance, if there are two viable processes for the production of a particular product, each owned by a different firm, the situation is akin to a 'prisoner's dilemma'. Unless restrained by mutual agreements, they would compete not only to supply products but also to supply their technologies. If one of the firms is an SEF, then the dilemma becomes more acute because the SEF can only exploit its innovation through licensing.

The textbook cournot oligopoly model, with constant (and symmetric) marginal costs and linear demand, is useful for understanding the logic. Licensing causes the number of producers to increase, so that the opportunity cost of licensing (to the licenser) is the decrease in profits. If the licenser shares the market with other producers, all other producers also experience a reduction in their profits as a result of the license, and the decrease in profits is larger for firms with bigger market share. ${ }^{19}$ Thus, an innovator has greater incentive to license in markets with more producers, because he would have a lower market share on average. Further, collusion between potential licensers would be difficult to achieve for the same reason. Similarly, licensing would be more prevalent in larger markets, with more potential entrants. These predictions are consistent with Lieberman's results discussed earlier. To the extent that the number of plants is correlated with the number of producers, Table 2 also bears this out. In sum, the greater number of producers after World War II itself increased the incentives for innovators to 1icense.

\section{Discussion and conclusions}

This paper is based on the experience of a single industry, and the conclusions drawn here may not

\footnotetext{
${ }^{18}$ Limited financial and managerial resources, lack of familiarity with international markets, as well as anti-trust considerations are obvious factors that would induce a firm to license.

${ }^{19}$ In technical terms, licensing imposes a negative pecuniary externality upon other producers, which is not taken into account by the licenser. This is because other existing producer will share the 'rent dissipation' as a result of an increase in entry, but will not share in the royalty payments that the licenser will receive.
} 
generalize to other industries. However, the chemical industry is the oldest of the 'high tech' industries, and remains one of the largest manufacturing industries. In 1995, the sales of the US chemical industry amounted to US $\$ 372$ billion (10.4\% of manufacturing value added), while those of Western Europe taken together amounted to US\$495 billion (CMA, 1996). Moreover, it is one of the few industries where patents have traditionally been important and effective (e.g., Levin et al., 1987), and where licensing is important (Anand and Khanna, 1996). Thus, lessons from the history of the industry are important in their own right, and may also have ramifications for other industries.

The history of the chemical industry shows that the traditional conceptualization of patents, with its focus on the tradeoff between the short term restrictive effects of monopoly and the longer term benefit of more innovation, is clearly inadequate. In the chemical industry, patents are often used in conjunction with other instruments, such as secrecy. Moreover, instead of being associated with discrete innovations, patents are more typically associated with technological areas, and firms often patent to wall off those areas. ${ }^{20}$ The efficacy and use of patents may depend on the underlying knowledge base. The limited understanding of the chemistry underlying the production and operation of organic dyestuffs limited the useful scope of patents, and encouraged secrecy about the production process. Conversely, the development of chemical engineering improved the usefulness of process patents, and encouraged patenting of processes.

The history of the chemical industry also shows that the role of patents is much broader than merely excluding competitors, and has changed in response to changes in industry structure. How patents are used (or not used) affects the opportunities for entry, industry structure, as well as the rate of technological change itself. The incentives to use patents to deter entry and to control the future development of the

\footnotetext{
${ }^{20}$ Some authors, most notably Merges and Nelson (1990), have argued that broad patents can thus inhibit technological progress. David (1992) notes that the restrictive effects of patents on the access to information on research methods and results may impose substantial efficiency losses in addition to the static 'deadweight loss' due to monopoly.
}

technology were high for market leaders in concentrated markets, especially during the inter war years. Patents were used to facilitate technology transactions within cartels, and were used to stabilize cartels by preventing entry into new markets by non-cartel firms. In other words, patents played an important role in maintaining concentrated market structures.

After World War II, two related developments proceeded apace. Many markets witnessed a significant amount of entry. As well, firms were far more willing to license their technologies. There were two related reasons for the increased technology licensing. First, the increase in the number of innovators, some of whom (SEFs) had no option but to license. The second reason was the growth in the size of the market and the number of producers. This availability, after World War II, of many qualified potential licensees made licensing more attractive. Technology licensing, often as a part of a package of technological know-how and other services, played a crucial role in lowering barriers to entry and deconcentrating markets. In other words, while the appropriability conditions affected market structure, the changed market structure itself affected appropriability conditions.

The emergence of SEFs contributed significantly to the growth of licensing in the post World War II period. The development of chemical engineering made process patents more useful and allowed process innovations to be separated from product innovations, and were important for the viability of these process specialists. More generally, patents play a crucial role in facilitating a market for technology because the strength and scope of patents affect not only the incentive to invest in research, but also the efficiency with which new knowledge is transferred to others. ${ }^{21}$

\section{Acknowledgements}

Many of the ideas presented in this paper are the product of an ongoing collaborative research effort

\footnotetext{
${ }^{21}$ Non patented knowledge, such as know-how is important in technology transfer (Taylor and Silberston, 1973). Patents can help here as well. Arora (1995) shows that simple contracts can accomplish the transfer of know-how provided patent protection is strong enough.
} 
with Alfonso Gambardella. I gratefully acknowledge several helpful conversations with Wes Cohen, and David Hounshell. Shane Greenstein, Nate Rosenberg, and anonymous referees of this Journal provided useful comments on earlier versions of this paper, which were presented at seminars at Wissenschaftzentrum Berlin für Sozialforschung, Stanford University, and the meetings of the AEA in Washington, DC. Partial financial support from the Technology and Economic Growth project at CEPR, Stanford University is gratefully acknowledged.

\section{References}

Aftalian, F., 1991. A History of the International Chemical Industry. University of Pennsylvania Press, Philadelphia.

Anand, B.N., Khanna, T., 1996. Intellectual property rights and contract structure, working paper \#97-016, Harvard Business School.

Arora, A., 1995. Licensing tacit knowledge: Intellectual property rights and the market for know-how. The Economics of Innovation and New Technol. 4, 41-59.

Arora, A., 1996. Contracting for tacit knowledge: The provision of technical services in technology licensing contracts. J. Dev. Economics 50 (2).

Arora, A., Gambardella, A., 1996. Evolution of Industry Structure in the Chemical Industry, mimeo, Stanford University, Stanford, CA.

Arrow, K.J., 1962. Comments on case studies. In: Nelson, R.R. (Ed.), The Rate and Direction of Inventive Activity: Economic and Social Factors. Princeton University Press, Princeton, NJ.

Backman, J., 1964. Competition in the Chemical Industry, Manufacturing Chemists' Association. Washington, DC.

Brooks, K., Watzman, A., 1986. New entries vie in chlorine technology. Chemical Week 139 (7), 22-23.

Chemical Manufacturers Association, 1996. U.S. Chemical Industry Statistical Handbook. Washington, DC.

Caves, R.E., Crookell, H., Killing, J.P., 1983. The imperfect market for technology licenses. Oxford Bulletin of Economics and Statistics, pp. 249-267.

Cohen, W.M., Klepper, S., 1992. The anatomy of industry R\&D intensity distributions. Am. Econ. Rev. 82 (4), 773-799.

Cohen, W.M., Levin, R.C., 1989. Empirical studies of innovation and market structure. In: Schmalensee, R., Willig, R.D. (Eds.), Handbook of Industrial Organization. Elsevier.

David, P.A., 1992. Intellectual property institutions and the panda's thumb: Patents, copyrights, and trade secrets in economic theory and history. Working paper \#287, CEPR, Stanford, CA.

Freeman, C., 1968. Chemical Process Plant: Innovation and the World Market, National Institute Economic Review, No. 45 (August), 29-51.

Haber, L.F., 1958. The Chemical Industry During the Nineteenth Century. Clarendon Press, Oxford.
Haber, L.F., 1971. The Chemical Industry: 1900-1930. Clarendon Press, Oxford.

Haynes, W.H., 1954. American Chemical Industry, vols. 1-6. Van Nostrand, New York.

Horstman, I., MacDonald, G., Slivinsky, A., 1985. "Patents as information transfer mechanisms: To patent or maybe not to patent." Journal of Political Economy, 93(5) October, 837858.

Hounshell, D.A., 1992. Managing industrial research and development in an era of globalization: Some implications from the chemical industry, Department of History, Carnegie Mellon University. (Unpublished paper).

Hounshell, D.A., Smith, J.K., 1988, Science and Strategy: Du Pont R\&D, 1902-1980, Cambridge Univ. Press.

Katz, M.L., Shapiro, C., 1986. How to license intangible property. Q. J. Economics, pp. 567-589.

Klepper, S., 1996. Entry, exit, and innovation over the product life cycle. Am. Econ. Rev. 86 (3), 562-583.

Landau, R., 1966. The Chemical Plant. Reinhold Publishing, New York.

Landau, R., Brown, D., 1965. Making Research Pay. AIChE-I Chem. E. Symposium Series No. 7, London Institute of Chem ical Engineers, London, pp. 7:35-7:43.

Levin, R.C., Klevorick, A.K., Nelson, R.R., Winter, S.G., 1987. Appropriating the returns from industrial $R \& D$. Brookings Papers on Economic Activity 14, 551-561.

Liebenau, J., 1992. The management of high technology: The use of information in the German chemical industry, 1890-1930. In: Kudo, A., Hara, T. (Eds.), International Cartels in Business History. University of Tokyo Press, Tokyo.

Lieberman, M., 1987. Patents, Learning by Doing, and Market Structure in the Chemical Processing Industries. Int. J. Industrial Organization 5, 257-276.

Lieberman, M., 1989. The learning curve, technological barriers to entry, and competitive survival in the chemical processing industries. Strategic Manage. J. 10.

Mansfield, E. et al., 1977. The Production and Application of New Industrial Technology. Norton and Company, New York.

Marsh, U., 1994. Strategies for success: Research organisations in German chemical companies and IG Farben until 1936. History and Technology 12 (1).

McMillan, F., 1979. Chain Straightners. Macmillan, London.

Merges, R., Nelson, R.R., 1990. On the complex economics of patent scope. Columbia Law Review 90 (4), 839-916.

Morris, G.D.L., 1989. The PP license battle. Chemical Week 144 (24), 18.

Mullin, R., 1993. Process technology: Business holds steady. Chemical Week 152 (1), 46-47.

Rotman, D., 1993a. Race to license new MTBE and tame routes heats up. Chemical Week 152 (1), 48-49.

Rotman, D., 1993b. Mobil/Badger to market zeolite-based cumene technology. Chemical Week 152 (7), 9.

Rotman, D., 1995. Lucrative markets attract new players. Chemical Week, p. 42, July 19.

Smith, J.K., 1992. National goals, industry structure, and corporate strategies: Chemical cartels between the wars. In: Kudo, A., Hara, T. (Eds.), International Cartels in Business History. University of Tokyo Press, Tokyo. 
Spalding, B.J., 1986. Is it smart to license out technology?. Chemical Week 138 (15), 30-31.

Spitz, P.H., 1988. Petrochemicals: The Rise of an Industry. Wiley, New York.

Taylor, G.D., Sudnik, P.E., 1984. Du Pont and the International Chemical Industry. G.K. Hall, Boston, MA.

Taylor, C.A., Silberston, Z.A., 1973. The economic impact of the patent system: A study of the British experience. University of Cambridge, D.A.E. monograph 23, Cambridge, CUP.
Teece, D.J., 1988. Technological Change and the Nature of the Firm. In: Dosi et al. (Eds.), Technological Change and Economic Theory, 1988. Pinter Publishers, London.

Travis, A.S., 1993. The Rainbow Makers: The Origins of the Synthetic Dyestuffs Industry in Western Europe. Associated University Presses, London.

von Hippel, E., 1990. Task partitioning: An innovation process variable. Research Policy 19, 407-418. 